\title{
GEMES PROJECT: VOCATIONAL SEAMANSHIP TRAINING PROGRAM SUPPORTED BY EUROPEAN UNION*
}

\author{
Oğuz ATík ${ }^{1}$ \\ Selçuk NAS ${ }^{2}$ \\ Ali Cemal TöZ ${ }^{3}$ \\ Burak Köseoğlu ${ }^{4}$
}

\begin{abstract}
The aim of this review article is to introduce Project "Gemes" and to raise awareness about seafarer shortage and unemployment matter in Turkey. The Project "Gemes", which is the Turkish acronym for "Vocational Seamanship Training for Proving Unemployed Youth Employment”, was a project partially funded by EU and successfully completed by Dokuz Eylul University in Izmir, Turkey. The Project focused on providing jobs onboard ships for a number of primary school graduates, unemployed young people between ages 18 and 24. The project mainly aims at making some contributions to the reduction of the regional unemployment in the medium and long term. Within this scope, another goal was to open up an opportunity for the work force and the employers in the region to meet and contribute to their coordination. The project was also designed to provide training program with high standards to bring up qualified employees in the maritime industry and set a model for curing the employment downfalls of the industry. In this context, it was initially intended to provide 120 beneficiaries with training and to ensure employment for a specific percentage. As planned
\end{abstract}

\footnotetext{
* Bu çalışma, 2011 yılında Hırvatistan’da düzenlenen “16. International Maritime Lecturers Association" (IMLA) Konferansında sunulmuş ve bildiri kitabında yayınlanmıştır.

${ }^{1}$ Lecturer, Dr., Dokuz Eylul University, Maritime Faculty, İzmir, oguz.atik@deu.edu.tr

${ }^{2}$ Assoc.Prof. Dr., Dokuz Eylul University, Maritime Faculty, İzmir, snas@deu.edu.tr

${ }^{3}$ Lecturer, Dr., Dokuz Eylul University, Maritime Faculty, İzmir, ali.toz@deu.edu.tr

${ }^{4}$ Lecturer, Dokuz Eylul University, Maritime Faculty, İzmir, burak.koseoglu@deu.edu.tr
} 
during the preparation of the project, trainings are continued with the contribution of the infrastructure gained, for the sustainability of the project.

Key Words : Youth employment, vocational seamanship training, european union project.

\section{ÖZET}

Bu makalenin amacı "Gemes" Projesini tanitmak, Türkiye'deki gemiadamı eksikliği ve işsizlik konularında farkındalık yaratmaktır. İssiz "Gençlerin İstihdamına Yönelik Gemiadamı Mesleki Eğitimleri" için kusaltma olan "Gemes” kusmen Avrupa Birliği tarafindan finanse edilmiş ve İmir Türkiye'de Dokuz Eylül Üniversitesi tarafindan başarıyla tamamlanmış bir projedir. Proje, 18 - 24 yaşları arasında, ilköğretim mezunu, işsiz gençlerin gemilerde istihdam edilmesine odaklanmıştır. Projenin ana hedefi, orta ve uzun vadede bölgesel işsizliğin azaltılmasına katkı să̆lamaktır. Bu kapsamda, projenin diğer bir amacı, bölgede işgücüyle işverenlerin bir araya getirilmesi için firsat yaratmak ve işbirliğine katkı sağlamaktır. Proje aynı zamanda, denizcilik sektörüne nitelikli işgücü yetiştirmek ve bu konuda sektördeki olumsuzlukların iyileştirilmesi için bir model oluşturmak üzere yüksek standartlara sahip bir eğitim programını hedeflemiştir. Projede bu kapsamda öncelikle 120 faydalanıcının eğitim alması ve belirli bir oranın istihdam edilmesi planlanmıştır. Projenin hazırlanması aşamasında planlandiğı üzere, projenin sürdürülebilirliği için projeden elde edilen altyapıyla eğitimlere devam edilmiştir.

Anahtar Kelimeler: Gençlerin istihdamı, mesleki gemiadamı ĕgitimi, avrupa birliği projesi

\section{INTRODUCTION}

The unemployment rate is approximately $11,9 \%$ in Turkey as of 2010, and the total increase in employment is 1,8 percent. While the population growth rate is $0,6 \%$ in the countries included in the European Union, that of Turkey is 1,52 percent (www.tuik.gov.tr, 2011). The visible growth experienced in the maritime sector in the world offers the youth who dream of a prosperous future a different alternative in terms of employment. For a job vacancy which is perhaps so vast like in no other sector appears in the maritime sector along with development. The deficit of seafarers is approximately 7,000 in Turkey (www.denizhaber.com, 2011).

However, the requirements of the international conventions for life, goods and environmental safety at sea and the national inspections thereon started to be applied in an increasingly strict 
manner all over the world especially in the last 10 years of the $20^{\text {th }}$ century. When one scrutinizes the applications in detail, one will see that almost all of the negativities result from the lack of training and incompetency of the seafarers. It is observed that such negativities result from the lack of investment and training.

World seas are the common rich of all the humanity from the past to the present but not of the individuals or individual countries. Further, maritime and sea transportation is an international field of business. The cost of any negativity caused by the lack of training of insufficiency of a seafarer is repaid not only by such seafarer or the shipping company by which he is employed but by all the world seas and all the humanity to cover the future generations as well. This is why the maritime training problems of the countries and the solution of such problems are addressed at international scale far beyond being national.

Dimensions and tonnages of ships have been gradually increasing in recent years in line with the technological developments and growing trade volume in our era and the increase in the number of those ships carrying dangerous substances especially including petroleum and in the quantity of dangerous cargo so carried poses a serious threat in terms of navigation, life and environmental safety. Particularly, petroleum products spilling over the sea as a result of the tanker ship accidents have caused environmental pollution. Analyses of the statistics on sea accidents have shown that accidents have reduced in line with the more use of modern technology in marine traffic, but that the percentage of the "human fault" has risen among the causes of accidents. It is stated in the August 1999 annual report of the British Marine Accidents Investigation Bureau (MAIB) that a great many accidents occur due to the use of unqualified work force preferred because they are inexpensive due to commercial pressure and economy (MAIB, 2011). The share of human fault is $80-85 \%$ in the statistics performed about ship accidents having occurred all over the world by IMO (IMO, 2011).

In 2008 a project call for "Active Labour Market Measures Grant Scheme" was announced by the Central Finance and Contracts Unit (CFCU) of Turkey. CFCU is taking the responsibility for the overall budgeting, tendering, contracting, payments, accounting and financial reporting aspects of all procurement in the context of the EU funded programmes in Turkey Within this scope, the Maritime Faculty of the Dokuz Eylul University has executed an agreement so 
that some of the most prominent maritime companies of Turkey undertook the role of participants in the employment of the youth that are a target group within the scope of project "Gemes" which is the Turkish acronym for "Vocational Seamanship Training for Proving Unemployed Youth Employment". Further, the faculty has signed a partnership contract with the Izmir Branch Office of the Chamber of Shipping and the Association of Solidarity of Maritime Labourers, with which the faculty has had close relations in its efforts to bring up seafarers for many years, thus guaranteeing to achieve the goals that it has anticipated in order to contribute to the increase in the employment in the region where it operates. The project shall contribute to the solution of the employment problem in the Izmir region as well as to the satisfaction of the need for seafarers in the maritime sector.

\section{EUROPEAN UNION - TURKEY FINANCIAL COOPERATION}

Until 2002 Turkey had received support under the MEDA programme and through two regulations to support the customs union and economic and social development. For the period to 1999 the key aim of assistance to Turkey had been to accompany the process of structural reform, as for other Mediterranean partners. Following the Helsinki European Council in 1999, a pre-accession orientation was introduced to the financial assistance programmes with Turkey. Assistance continued to be available for structural adjustment, in coordination with the international financial institutions, but assistance also began to focus on institution building, investment, and supporting the participation of Turkey in Community programmes and agencies. The Council adopted on 17 December 2001 a regulation concerning pre-accession financial assistance for Turkey. The regulation reiterated the Commission's objective to establish pre-accession financial assistance, on average, at an annual level of 177 million. In its Strategy Paper of 2002, the Commission envisaged that total assistance should be substantially increased, taking into account Turkey's needs and absorptive capacity. The Copenhagen conclusions confirmed that from 2004 this assistance would be financed under the "pre-accession expenditure" heading of the 2000-2006 financial perspectives. The Commission has adopted on 12 February 2003 a proposal to this effect in COM (2003)70 of 11.02.2003 and transmitted it to the Budget Authority (www.cfcu.gov.tr, 2011). 
During the period 2004-2006 pre-accession financial assistance will focus on supporting Turkey's efforts to meet the Copenhagen criteria, with special attention to the political criteria and in particular to strengthening institutional capacity and investment related to the adoption of the acquis. Assistance will also be available for improving the functioning of Turkey's economy and its capacity to cope with competitive pressure within the internal market. Crossborder co-operation with EU Member States and candidate countries will also be promoted. As for all candidate countries, assistance will fall under two main headings which are institution building and investment (www.cfcu.gov.tr, 2011).

\section{AIM OF THE PROJECT}

It is observed that the unemployment rates are rather high in the three large cities - Istanbul, Ankara and Izmir of Turkey, which are under an intense pressure of immigration, despite the reduction observed in recent years. It is further observed that, of the three large cities, Ankara has the highest rate of unemployment $(15,9 \%)$ followed by Izmir $(14,9 \%)$ and Istanbul (13,7\%). Lack of supply of the qualified work force of the qualifications and number as required by the business world is a general problem of our country (TUIK, 2005).

It is seen that unemployment has reached a high percentage and is 3 points beyond that of Turkey $(13 \%)$. In particular, it is found out that unemployment is at alarming dimensions in terms of the unemployment of the youth (15-24 years of age) unemployment and that 23 out of 100 youth are unemployed in Izmir (TUIK, 2005).

While the unemployment rate in the sector included in the definition of young workforce is parallel with the average of Turkey in the Aegean Region, it is higher in Izmir in particular. The unemployment rate in the young workforce which was approximately $25 \%$ in Izmir in 2004 only reduced to $22,5 \%$ in 2005 (TUIK, 2005).

Job seeking time of the unemployed youth in the range of 1524 years of age increased between 2003 and 2006. While 20 out of 100 unemployed youth sought employment for a period of more than a year, 33 out of 100 unemployed youth were unemployed for a long period of time and their number increased from 193,000 to 280,000 in 2006. Thus, $32 \%$ of the long-term unemployed consisted of the youth in 2006. Hopelessness also increased among the youth in the 15-24 age group who must be hopeful for the future along with the job 
seeking time. While the number of those youth who had no hope of finding a job was 39,000 people in 2003 , it reached 280,000 people in 2006 and $40 \%$ of the hopeless consisted of the youth who are our hope. Thus, while there were 4 hopeless youth for 100 unemployed youth in 2003, there were 33 hopeless youth for 100 unemployed youth in 2006 (TUIK, 2005).

Within this scope, the target group of this project which has been established in order to make some contribution especially to the employment of the unemployed individuals between 18 and 24 years of age who are its target audience consists of the young population comprising one third $(1,319,000)$ of the total population of Izmir.

It was aimed that the 120 beneficiaries who shall be trained by the academic personnel employed by DEU providing undergraduate training in maritime, who all have marine experience, complete the training at a rate of $90 \%$.

Practical and theoretical training of 240 hours was provided within the scope of the project in compliance with the "Ordinary Seaman and Oiler Special Training" whose standards are stipulated in the Seafarers Training and Examination Regulations. Trainings were provided to 3 groups of 40 people (20 Ordinary Seamen and 20 Oilers) for 2 months in 3 terms. It was aimed that those beneficiaries who proved to be successful at the end of training shall be successful at a rate of $90 \%$ in the examination to be held by those Port Masters authorised by the Undersecretariat for Maritime Affairs so that they acquire proficiencies and obtain "Seafarer Proficiency Certificates".

It was aimed that $80 \%$ of those beneficiaries who have passed the seafarers examination and obtained their proficiencies shall be employed as Ordinary Seamans and oilers on board the ships as owned by our participants who have a say in the maritime sector.

The project intended to make some contribution to the reduction of the regional unemployment in the medium- and longterms. Within this scope, to make some contribution to cause the workforce in the region and the employers in the sector to meet and ensure coordination between them was part of the general goal. 


\section{DESCRIPTION OF THE PROJECT}

The project which was commenced between 01.12.2008 and 30.11.2009 aimed at making some contribution to the reduction of the regional unemployment in the medium and long term. Within this scope, another goal was to cause the work force and the employers in the region to meet and to contribute to their coordination. Planning to provide training to bring up qualified employees in the maritime sector, Dokuz Eylul University Maritime Faculty maintained the training in terms of the sustainability of the project, thus displaying its determination as to the permanency of the employment. In this context, it was initially intended to provide 120 beneficiaries with oiler and ordinary seaman training and to ensure employment at a rate of $65 \%$ under the project. It was intended to uninterruptedly continue trainings with the contribution of the infrastructure acquired as from the completion of the project. Project Framework below summarizes the progress (Table 1). The budget of the project was 141.076,29 Euro. Table 2 shows the budget summary.

\section{DESCRIPTION OF THE ACTIVITIES}

After the formation of the project team which consists of the academic personnel of the Faculty with sea experience, progress started to promote the project and to identify the beneficiaries who befit the criteria. At this stage, project was started to be promoted and the target group selected from the target audience. Preparation of the training infrastructure was one of those activities of the project which first started, and within this scope, efforts for tender purchase and infrastructure was maintained to create a ship forecastle deck model on campus. Activities for oiler and ordinary seaman training commenced once the training infrastructure has been completed. Visibility activity was maintained throughout the project. Upon such formalities as the issuance of the Seaman Books, obtaining of the health reports of the beneficiaries and the registration for Seamanship Examination, the Faculty collaborated with the project partners in the activities of employing the beneficiaries. Monitoring, assessment and reporting activities were carefully performed so that the project was efficiently implemented, and external assessors were used within this scope. 


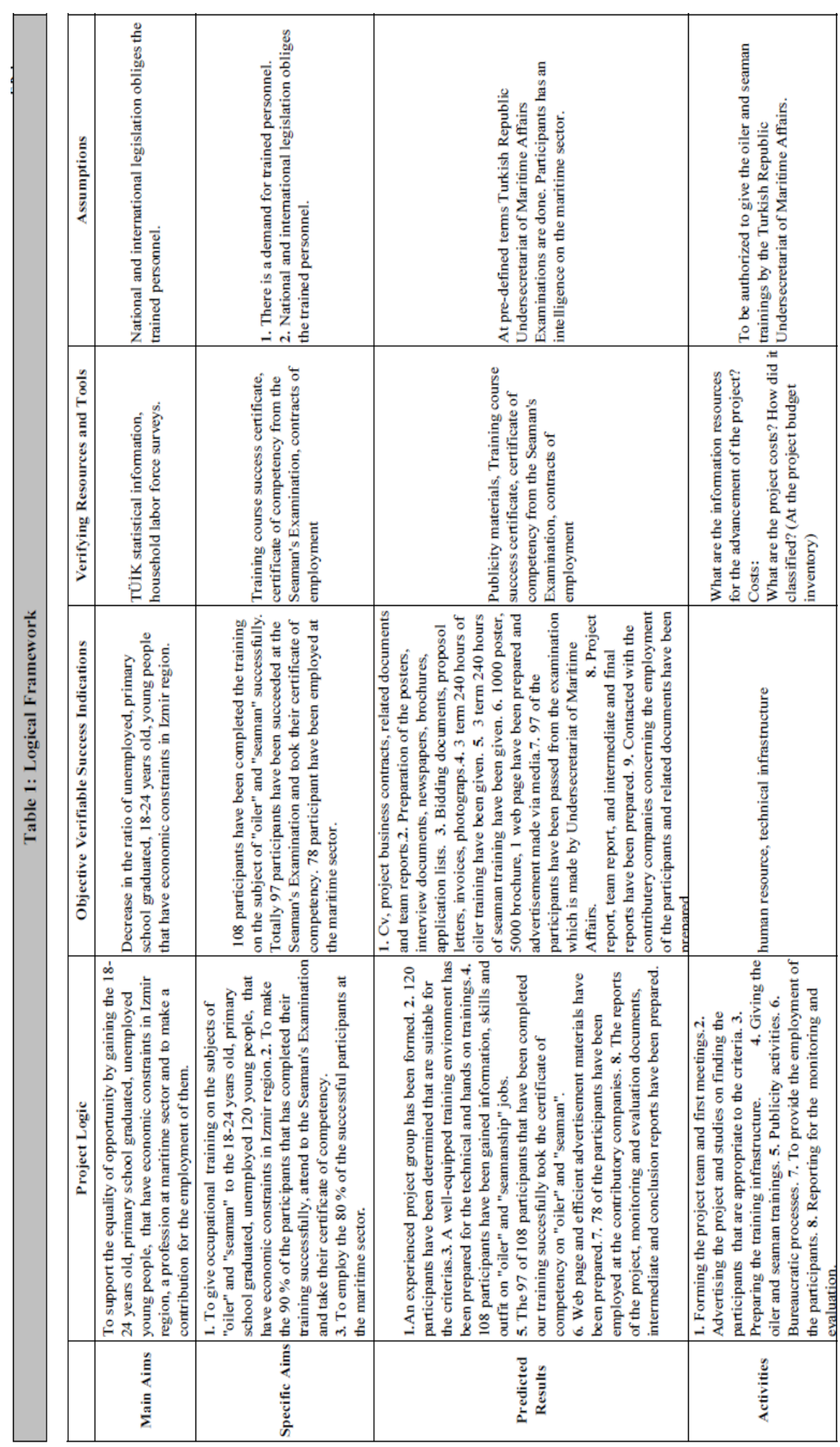


Table 2. Part of the Project Budget Summary

\begin{tabular}{|c|c|}
\hline \multicolumn{2}{|l|}{ BUDGET } \\
\hline \multirow{2}{*}{ BUDGET LINE } & BUDGET \\
\hline & (EURO) \\
\hline 1. Human Resources & 64200 \\
\hline 2. Travel & 1200 \\
\hline 3. Equipment and Supplies & 39597 \\
\hline 4. Local office/Action costs & 1800 \\
\hline 5. Other costs, services & 7050 \\
\hline 6. Other & 18000 \\
\hline $\begin{array}{l}\text { 7.Subtotal direct eligible costs of the Action } \\
(1+2+3+4+5+6)\end{array}$ & 131847 \\
\hline \multicolumn{2}{|l|}{ 8. Provision for contingency reserve } \\
\hline \multicolumn{2}{|l|}{ 9. Total direct eligible costs of the Action(7+8) } \\
\hline 10. Administrative costs & 9229,29 \\
\hline 11. Total eligible costs $(9+10)$ & 141076,29 \\
\hline \multicolumn{2}{|l|}{ Sources of Funding } \\
\hline \multirow{2}{*}{ RESOURCE } & BUDGET \\
\hline & (EURO) \\
\hline 1. Eu Contribution & 126968,66 \\
\hline 2. Applicant's financial contribution & 0,00 \\
\hline $\begin{array}{l}\text { 3. Contributions from other organisations } \\
\text { (partners/sponsors) }\end{array}$ & $14.107,63$ \\
\hline TOTAL & 141076,29 \\
\hline Direct revenue from the action & 0 \\
\hline Interest income & 0 \\
\hline
\end{tabular}

\section{PROJECT PARTNERS}

Dokuz Eylul University Maritime Faculty agreed with The Izmir Branch Office of the Chamber of Shipping, The Association of Solidarity of Maritime Laborers, and 9 of the Turkey's largest shipping companies to work together in the project.

\subsection{Izmir Branch Office of the Chamber of Shipping (DTO)}

The substantial objectives of the Chamber of Shipping are to cover the common needs of the seafarers, develop the maritime profession, facilitate professional activities, establish common rules, 
make suggestions to the competent authorities with regard to the problems of the maritime, protect the discipline, ethics and solidarity in the maritime profession and ensure the development of the marine trade in accordance with the national transportation policy. The Izmir Branch Office of the Chamber of Shipping has contributed to provide some 30,000 young individuals in the training of seafarers together with DEU Maritime Faculty since 1996. Within the scope of the project, it rendered secretarial services as to the notifications to the unemployed youth and the collection of requests. It supported the Faculty to ensure liaison between the maritime sector and those beneficiaries who have completed their training and to make contribution to their employment during the term of the project.

\subsection{Association of Solidarity of Maritime Laborers (DADDER)}

The Association of Solidarity of Maritime Laborers carries out works to protect the rights of the seafarers as to the work place security, health and safety, to enter into contracts and agreements on behalf of the employees and perform legal formalities under the cooperation with the International Federation of Transportation Laborers. It organizes conferences about the condition of the maritime sector and training at DEU Maritime Faculty. It made a significant contribution to the project in the preliminary assessment of the companies (Project Participants) by which the project beneficiaries were employed in terms of work place security, health and safety. Further, it has also undertaken the task of ensuring the inspection of whether or not the companies by which the project beneficiaries were employed are in compliance with the international labour standards and the observance of their labour rights.

\subsection{Project Participants}

The nine most prominent shipping companies of Turkey took place as participants in the project. All of the participants are Ship owning Corporations and Commercial Enterprises. The project participants own and operate ships rendering transportation services in all the seas of the world. The average number of seafarers of our participants who work at sea is 260 and they employ at least 3 oilers and 5 seamen with the proficiency of seafarer on board each ship they operate. Relationship of the participating companies with the Faculty goes on via the conferences at the Faculty by the company executives, their contribution in kind and their attendance to the Career Days regularly organized at the Faculty. They have undertaken tasks in the 
employment of the beneficiaries during and after the project and the communication to the project organization of the job performance data and feedback to be assessed in the course of the working period of the beneficiaries so employed. Further, a portion of $10 \%$ of the total reasonable cost of the project was divided among the project participants.

\section{FINAL BENEFICIARIES OF THE PROJECT}

Considering the final beneficiaries in general terms, the ship owners and operators who are a prominent element in the Turkish Maritime Sector shall take one more step toward the solution of the problem of the restriction of qualified and trained intermediate employees to be employed on board of their ships at the termination of this project.

Upon the creation of employment only for the youth who have completed their primary education due to different reasons, the families of such individuals shall also benefit. Considering that such individuals who have chosen as the target group shall start working for reasonable wages, it is definite that the families of the beneficiaries of the project shall also have an economic benefit.

It should not be overlooked that social benefit shall also be achieved via the project. As the maritime sector is not well known due to its special structure, this project shall also ensure the people of the region to be informed on maritime.

The shipping practice laboratory which was established under the project made some contribution to the existing infrastructure of DEU Maritime Faculty. With the infrastructure established during the project trainings continue after the termination of the project.

\section{CONCLUSION}

The most significant output is considered to be the successful completion of the training and achievement in the seafarers' examination by and provision of employment for the target audience which was the basic goal of the project. Within this scope, employment contracts, social security documents, accession and quit orders, proficiency certificates, seafarer certificates are considered the most important verification documents of such output. 
Another important activity is the improvement of the training infrastructure and its updating within the scope of such training. The most important output of this activity is the materials to be used in the training infrastructure. In particular, the supply of the ship forecastle deck model provided by ship dismantling from a shipyard.

Another important output is to ensure the covering of the qualified and trained personnel deficit on board the ships of the participating companies. Within this scope, the feedback to be received from our participants is the most significant verification resource of this output. Thus, it is anticipated that any safety problems on board ships and occupational accidents caused thereby shall be prevented. The statistical data to be received from the participants as an output of this anticipation shall be subjected to evaluation in the post-project period.

Sustainability of the project is ensured by continuing to bring up qualified Ordinary Seamen and oilers with the experience and specific infrastructure acquired upon the termination of the grant and the performance of the activities.

The ship engines simulators and laboratories available in the Ship Engines Operation Engineering Department of the faculty, the simulators of the Deck Department which were used for trainings under the project and other training facilities and the ship model and shipping laboratory which were situated within the limits of the school under the project contribute to more qualified provision of such trainings especially in the province of Izmir. These laboratories are also used for the training of the students of our school. Thus, a significant support has been provided for the infrastructure of the faculty as well.

First, it is thought that some contribution, though small, shall be made to the EU membership process of our company by this project. In case the feedback received upon the performance of the activities of the project is affirmative, the importance of improvement of the qualifications of the personnel who shall be employed on board ships shall have been proven from the standpoint of the maritime sector. More productive operation of the ships with the qualified and trained personnel shall indicate how efficient the decision of "mandatory seafarer and trainings" made by the Undersecretariat for Maritime Affairs is. Within this framework, it is anticipated that the 
importance placed on maritime training shall be enhanced and improved in the legal and legislative meaning.

One of the most prominent multipliers of the project is its contribution to the development of social conscious of the beneficiaries. Another multiplying effect is the contribution to the productivity of the communication and coordination within the maritime sector as well as between the parties in the sector. It was planned to make some contribution to the training quality of the faculty with the infrastructure so provided. Another multiplying effect is the increase in the level of consciousness about the EU in the society. In the long-term, contribution shall be made to the reduction of the regional unemployment by means of the sustainability of the project.

\section{REFERENCES}

Deniz Haber. 2011. "Denizcilik Sektöründe 7 Bin Gemiadamı Açığı". http://www. denizhaber.com/HABER/8536/2/. (Accessed 12 June 2011)

International Maritime Organization. 2011. "Tanker safety: the work of the International Maritime Organization", Focus on IMO, United Kingdom, London.

Marine Accidents Investigation Branch. 1999. "Annual Report". http://www.maib.gov.uk/publications/annual_reports/annual_report_1 999.cfm. (Accessed 10 June 2011).

The Central Finance and Contracts Unit. (2011). http://www.cfcu.gov.tr/ about.php ?Ing.=en \&action=cfcu. (Accessed 13 June 2011).

Turkiye İstatistik Kurumu. (2008). "İşüucü İstatistikleri". http://tuikrapor.tuik.gov.tr/reports. (Accessed 15 March 2008).

Turkiye İstatistik Kurumu. (2011). “İşgücü İstatistikleri”. http://tuikrapor.tuik.gov.tr/reports. (Accessed 12 June 2011). 